affairs, but also as affording an indication of the line along which it is at present the aim of the allied powers responsible for colonial dependencies to direct future and post-war policy in inter-State relations. The British Government, earlier in the present year, pledged itself to a policy of colonial development so far as conditions might allow during the continuance of hostilities ; while, in administration, liaison arrangements with the French Colonial Empire had already been brought into operation before the collapse of France. This co-operation between Colonial Governments, Lord Lloyd stated, has not only begun but is also being deepened every day during the War, and will be continued afterward when all the Colonial Governments will be free from the daily fear of Nazi aggression.

In support of this statement, Lord Lloyd was able to point to the important economic agreements which have been negotiated with the Free French colonies in Africa and with the Belgian Congo. Further, the British Colonial Office has organized within the office to continue the liaison arrangements with the French Colonial Empire. Recent developments in relations with the Dutch colonial authorities are even more striking. The British and Dutch Governments have been so strongly impressed by the results of joint discussion of problems common to Malaya and the Dutch East Indies, which have taken place both in England and between Sir Shenton Thomas and the Netherlands authorities in Batavia, that regular machinery has been set up to ensure that liaison in the form of a joint Anglo-Netherlands Committee on Economic Matters.

While these measures to promote a liaison in the important sphere of economics are a substantial beginning in the promotion of co-operation in administration between Colonial Powers, which will prove of the greatest value in planning post-War development in the Colonies under British administration, Lord Lloyd referred also to measures which, if less spectacular, should nevertheless have the practical result of assisting them in the initial stages of coping with the difficulties of the present situation. For the moment, action is directed in the main towards keeping up essential supplies in so far as is necessary to avoid war-time distress and to maintain the standard of living. Apart from special forms of assistance, financial and other, this has entailed urging upon the Colonies to grow more and better kinds of food, and in the relation of exports and imports to ensure that cash provided should be turned into essential supplies from outside. In this connexion Lord Lloyd pointed out that, in the past, the Colonies have concentrated too much on the production of some profitable export crop and have relied upon imports for their necessary foodstuffs. His predecessors, he added, for some years past had urged upon Colonial Governments the importance of mixed farming, by which the soil would be enriched and a better balance secured in agriculture. It is to be presumed that no opportunity in the future will be lost to stress the advantages of a policy for which the argument is now so greatly reinforced by the urge of necessity.

\section{Dr. F. B. Jewett}

THe resignation of Dr. Frank B. Jewett, president of the National Academy of Sciences, from his post as president of the Bell Telephone Laboratories, Inc., in New York City, has recently been announced. He now becomes chairman of the Board of Directors, and will thus have more time to aid the U.S. Government as a member of the National Defence Research Committee. He will be succeeded as president of the Laboratories by Dr. O. E. Buckley, who has been executive vice-president. For the past twenty-four years, Dr. Jewett has been the operating head of the Bell System's research programme, and since 1930 has been responsible both for the programme and its execution. He will now continue as vice-president of the American Telephone and Telegraph Company, in charge of research, as such retaining his jurisdiction over these activities. Dr. Buckley, new president of the Laboratories, has been associated with telephone research since he entered the Bell System in 1914. $\mathrm{He}$ became director of research in 1933 and executive vice-president in 1936 (see also p. 824 of this issue).

\section{Jacob Petersen}

Dr. JACOB Julius Petersen, a well-known Danish medical historian, was born at Rönne in the island of Bornholm on December 29, 1840. $\mathrm{He}$ studied medicine at Copenhagen, where he qualified in 1865. After a visit to Germany, where he worked under Virchow and Traube in Berlin, he settled in Copenhagen. Besides his activities as a communal doctor he delivered lectures on the history of medicine from 1874 onwards, but it was not until 1887 that he received official recognition as a lecturer, and in 1890 was appointed extraordinary professor of medical history in the University of Copenhagen. His chief publications were on the contagion of tuberculosis (1869), chief factors in the historical development of medical treatment (1876), the older history of clinical medicine (1889), cholera epidemics with special reference to Denmark (1892), Danish medicine in the years 1700-1750 (1893), and smallpox and vaccination (1896). He died on May 28, 1912.

\section{Museums and the Public}

There is an aspect of museum work and museum service to the community of which little is heard and which nevertheless occupies a considerable part of the duties of the staff and is of some national importance. It concerns minor inquiries of many sorts which can be answered only by a specialist, and the answers to which may be of some value to the inquirers. Some of the miscellaneous economic problems placed before the Department of Botany in the Free Public Museums of Liverpool are instanced by $\mathrm{H}$. Stansfield in an article in the Museums Journal $(40,215 ; 1940)$. A young woman was given a cigarette, collapsed on smoking half of it and remained unconscious for two days. The cigarette had been home-made by a man who used the leaves of a plant growing accidentally in his garden; the botanist identified the plant as Indian hemp, the 